\title{
Applied Chauvinism: Building Collections of State Literature
}

\section{LAWRENCE S. THOMPSON}

In the summer of 1940 I arrived in Ames, fresh out of Ann Arbor, where I had been effectively indoctrinated (not in library science classrooms) by Randolph G. Adams, the apostle of the rare book in America. It was a challenge to imagine ways to implement Adams's abiding notion that effective and practical rare book collections can be developed most anywhere on most any subject. There was a nagging fear that my new chief, Charles $\mathrm{H}$. Brown, a towering figure in American academic library circles in the twenties and thirties, would have little sympathy. I had forgotten that Brown had won his library spurs at the Library of Congress in the early Putnam days and had matured professionally at the Crerar of Clement W. Andrews and J. Christian Bay.

Brown saw the logic of building a file of Torch Press imprints. He had no objection to cataloging in full and putting in the single row of locked cases a pristine first edition (1906) of Pigs Is Pigs, acquired for 15 c, although Ellis Parker Butler's death a couple of years earlier made it impossible to ask for a replica of the alleged inscription to the old Travelling Library in Des Moines in response to its request for a free copy: "To the State of Iowa, which spends millions for manure, not one cent for culture." My greatest triumph at Ames was when I left Brown's office with an OK on an order slip to Nijhoff for the 1542 edition of Leonhart Fuchs's Historia stirpium for \$75-the prime piece of Iowana with the first picture of Zea mays.

It was just as well that my stay at Ames was cut short by events of December 7, 1941. Had I returned, I would surely have come out a distant second-best to Frank Paluka as the architect of a great collection of Iowana. And properly so: A half century of personal and institutional collecting, with special emphasis on regional literature, has convinced me that there should be a single flagship collection in this area, either in the original state university library or in the state historical society, at least in the South and Middle West. The Northeast has different library tradi- 


\title{
Iowa Authors
}

\author{
A B IO-BIBLIOGRAPHY OF \\ SIXTY NATIVE WRITERS
}

Frank Paluka

I O WA C I T Y, IOWA

Friends of The University of Iowa Libraries

Title page of Frank Paluka's path-breaking bibliography of Iowa writers. 
tions. Unproductive competition between institutions for acquisition of regional materials can be particularly insidious.

On the other hand, every general collection, from the elementary school library on up, should develop collections of regional literature in proportions tailored to its own needs. The United States has reached such a point of size and maturity that every state has writers of stature who can provide a gateway through the familiar to the broader realms of world literature. The flagship collection can be of considerable help to all other libraries.

The first and essential step is to be immersed thoroughly in the bibliographical literature of the region. In 1944 I found myself in Puerto Rico and became enthusiastic for the flourishing Afro-Antillean poets of the day, then for the broader field of the entire insular literature. I was lucky enough to pick up a copy of Antonio S. Pedreira's Bibliografía puertorriqueña (1932), studied it like a catechism, prowled through the compiler's great personal collection in the University Library in Rio Piedras. My career as a collector of Borincana was even shorter than that as a collector of Iowana; but a couple of years later I recognized a batch of pamphlets in a Havana junkshop as material recorded by Pedreira. I picked it up for $\$ 2$ and found, inter multa alia, the first nonserial Puerto Rican imprint, unknown to Pedreira. The whole was in a nineteenthcentury Cuban cigar box, later traded to a tobacco collector for his duplicates of flyers and posters relating to the Tobacco War and the night riders of western Kentucky in the first decade of this century. The latter have found their way into our national literature through Robert Penn Warren's novel with this title.

The lesson served me well upon arrival in Kentucky. The late David Clift's distinguished service as American Library Association executive secretary (1951-73) never allowed him to get well started on the bibliography of the fiction of his native state. I told him that if he didn't, I would, and received his blessing and invaluable help along the way to the completion of The Kentucky Novel (1953). Far and away the most important aspect of this project was the successful courtship of my coauthor and cocollector of 12 short years. But we discovered much else. We learned how and where to find better copies than the cats and dogs on the shelves of the University of Kentucky Library, from the rich stocks of Wright Howes and Mike Papantonio to a small-time antique dealer in Paducah and a bibliophilic barber in Cadiz, Kentucky. We met personally or by correspondence many of the noted contemporaries, often acquiring 
manuscripts and correspondence along the way, or commitments (generally fulfilled ultimately) to deposit the material in our library.

There were all sorts of by-products. In hunting for biographical information on the author of a temperance novel, we stumbled across a collection of temperance songbooks, sermons, youth manuals, cartoons defaming Demon Rum, Prohibition party literature, and much else related to the subject. I would have preferred to have fought a hangover from our famed Golden Pond rotgut from Trigg County than to have cleaned the bushels of pigeon droppings from this barn loft treasure, but students of the American temperance movement are much better equipped after my scatological chore. Incidentally, I have never located a single written line by Carrie Nation, a native of Garrard County, Kentucky.

The temperance novel incident suggests the recurring criticism that regional collections are heavily laden with garbage. Indeed they are, and so were the trash piles of Oxyrhynchus and the kitchen middens of the Viking age. Our best-known subliterature of the last century, the dime novels, was furtively read by our grandfathers in dimly lit smokehouses, but it is the basis for an enduring popular conception of the frontier and its characters. John Fox, Jr.'s stereotype of homo Appalachiensis is still more influential than the vastly more subtle characters of Harriette Arnow and Wilma Dykeman. A prime rule in collecting a state's literature is to recognize the importance of the unimportant, to snap up the apparent junk before it disappears or becomes as expensive as the dime novels are today.

In formulating policy for a collection of state literature the first step is to define the limits of inclusion-and to provide for breaking these policies judiciously. It is not enough simply to say that every author born in the state, active in the state, or who used state themes is to be included. It would be unwise to start a collection on Theodore Dreiser in a Kentucky institution; but it would also be a dereliction not to have built a collection of photographs, clippings, and ephemera on the activities of Dreiser and other writers in Bloody Harlan in the 1930s. Malcolm Cowley has elected to deposit his archive in the Newberry; but we borrowed from Mr. Cowley photographs recording a literary visit in western Kentucky with Allen Tate, Caroline Gordon, and Robert Penn Warren.

It is open to question whether we should have requested the manuscript of Herman Wouk's Youngblood Hawk, set in Kentucky and researched in our library. It is unlikely that he will have another Kentucky association. Perhaps it was all right, certainly would be if all librarians were as sensible as Fred Adams of the Morgan, whose 
dedication gift to the Lilly Library was the "return" of a manuscript of General Lew Wallace of Crawfordsville. One must be careful about collecting items with associations that are too slender. Every now and then I am compelled to suppress a yearning for the privately owned handwritten manuscript of John Cowper Powys's Wolf Solent, written on the verso of stationery from the old Helm Hotel in Bowling Green, Kentucky.

Identification of authors as belonging to a particular state can be abused. The late John Wilson Townsend's well-known anthology, Kentucky in American Letters (printed at the Torch Press, as were several other of his books) promoted the notion that a Kentuckian born doesn't have to be a Kentuckian bred to enjoy the "patent of nobility" conferred by the place of his birth (Timothy Flint). He includes Senator George Vest, but the State Historical Society of Missouri will never have a fight with us about custody of the manuscript of the "Eulogy to the Dog." Governor Proctor Knott spent his life in Boyle County, Kentucky, and is remembered nationally for his satirical speech on Duluth. The Minnesota Historical Society is welcome to a photocopy. We have no special interest in competing with another library for the papers of Robert Lowell because of his marriage to Elizabeth Hardwick of Lexington. Hers, definitely yes.

Fragmentation of collections is less serious than it was in the prephotocopy age. Theodore Roosevelt's letters to John Fox are in Lexington, Fox's to Roosevelt at Harvard; but this is not an aggravating situation. It is inevitable that the correspondence of James Lane Allen is scattered all over the country, with relatively few in Lexington. The most important thing is to encourage contemporaries to select a single depository, even at the risk of sacrificing a partial collection. The republic of learning will be served much better over the long haul.

The question of appropriate locations and transfer of materials to a place most convenient for scholars can be a vexed one and even stir up animosity. It was difficult to conceal my horror from Allen Tate (of Clark County, Kentucky) when he replied to a request for a handwritten poem that he could ask Princeton to transfer his deposits there to us. It wasn't easy to compose a gracious reply.

The opposite situation occurred with the late Rebecca Caudill, one of the ablest writers of Appalachian children's books. She had deposited her scrapbooks and other material in an eastern Kentucky public library near her birthplace. When the proposal was made that the material might be lent to us for filming, both she and the library realized that the material would be more accessible to students of children's literature if it were in Lexington. This is an egregious example of the responsibility of a flagship 
library to maintain its position aggressively but tactfully. Only in my most private thoughts are prayers for the security and proper care of Jesse Stuart's archives in his colorful but remote home in W-Hollow in Greenup County.

A collection of state literature should not overlook the work of noted scholars and critics who are natives. That they generally make their careers elsewhere creates a difficulty. The most appropriate home for the papers of Cleanth Brooks of the Jackson Purchase in western Kentucky is probably Yale, but we have collected as much of his work as possible, including textbooks, offprints, and clippings. I had known Stith Thompson as a respected elder statesman of folklore and had most of his books, some of his offprints (not directly from him, rather a gift of Archer Taylor). Genealogical studies on both sides revealed to us that we were sixth cousins, and I learned that he was born in Boyle County. I did ask him to complete my file of his offprints and ephemera, but it would be unthinkable that his basic archive should not be at Indiana, which he had made the folklore capital of the U.S.

One of the most gratifying and productive aspects of regional collecting is the camaraderie that develops between authors, collectors, and librarians on the common basis of a love for familiar landscapes. Ben Lucien Burman, who died close to 90 last year, left his native Covington, Kentucky, to go to Harvard, spent his whole mature life in New York. He was totally delighted to be recognized as a Kentucky author, eager to deposit his work in Lexington. The Burman collection is valuable, but I treasure my friendship with this charming gentleman even more.

There are always stories of the big ones that got away. My first state collection dealt with my native North Carolina. I used to visit Tom Wolfe in his unbelievably messy place in the old Chelsea Hotel on Twelfth Street. The place was littered with discarded manuscript, thousands of pages of it. If I had only had the imagination to apply to the super for a job as assistant janitor, I could have picked up enough stuff to keep Wolfe's textual editors busy well into the twenty-first century.

The successful collector of state and regional literature needs bibliographical acumen; a sixth sense for locating books and manuscripts; and sensible and scrupulous relationships with collectors, dealers, and colleagues. Indeed, these are also the attributes of any competent collector. Add to this list miscellaneous janitorial skills in cleaning littered city apartments and rickety old barns, and you have a Draper redivivus. 